CZASOPISMO INŻYNIERII LĄDOWEJ, ŚRODOWISKA I ARCHITEKTURY JOURNAL OF CIVIL ENGINEERING, ENVIRONMENT AND ARCHITECTURE

JCEEA, t. XXXIV, z. 64 (3/I/17), lipiec-wrzesień 2017, s. 103-114, DOI: 10.7862/rb.2017.107

\author{
Andrzej GRUCHOT ${ }^{1}$ \\ Eugeniusz ZAWISZA ${ }^{2}$ \\ Ewa CZY $\dot{Z}^{3}$
}

\title{
PARAMETRY KONTAKTU MIĘDZYFAZOWEGO WYBRANYCH MATERIAŁÓW STOSOWANYCH W BUDOWNICTWIE ZIEMNYM
}

\begin{abstract}
Celem badań było określenie wytrzymałości na ścinanie mieszaniny popiołowożużlowej ze składowiska odpadów Elektrociepłowni Kraków (EDF Polska S.A.) oraz oporu tarcia międzyfazowego na kontakcie pomiędzy przedmiotową mieszaniną a geowłókniną PPST 100. Badania przeprowadzono w aparacie bezpośredniego ścinania. Próbki do badań formowano w skrzynce aparatu przy wilgotności optymalnej przez ich zagęszczanie do Is $=0,90$ i 1,00 . Ścinanie próbek przeprowadzono bez i z ich nawodnieniem.

Parametry wytrzymałości na ścinanie mieszaniny popiołowo-żużlowej były duże. Stwierdzono istotny wpływ zagęszczenia, którego wzrost spowodował zwiększenie kąta tarcia wewnętrznego i spójności. Natomiast nawodnienie próbek spowodowało zmniejszenie parametrów wytrzymałości na ścinanie. Wartości parametrów oporu tarcia międzyfazowego na kontakcie mieszanina popiołowo-żużlowa a geowłóknina były również duże. Należy również wskazać, że nawodnienie próbek spowodowało zwiększenie kąta tarcia międzyfazowego i zmniejszenie adhezji. Można więc stwierdzić, że stosowanie mieszanin popiołowo-żużlowych jako kruszywa antropogenicznego jest ważnym i istotnym zagadnieniem $\mathrm{w}$ aspekcie ochrony naturalnych materiałów gruntowych.
\end{abstract}

Słowa kluczowe: mieszanina popiołowo-żużlowa, wytrzymałość na ścinanie, opór tarcia międzyfazowego, geowłóknina

\footnotetext{
${ }^{1}$ Autor do korespondencji / corresponding author: Andrzej Gruchot, Uniwersytet Rolniczy im. H. Kołłątaja w Krakowie, Wydział Inżynierii Środowiska i Geodezji, Katedra Inżynierii Wodnej i Geotechniki, al. Mickiewicza 24/28, 30-059 Kraków, tel. 126624161, e-mail: rmgrucho@cyf-kr.edu.pl

${ }^{2}$ Eugeniusz Zawisza, Uniwersytet Rolniczy im. H. Kołłątaja w Krakowie, Wydział Inżynierii Środowiska i Geodezji, Katedra Inżynierii Wodnej i Geotechniki, al. Mickiewicza 24/28, 30-059 Kraków, tel. 126339098, e-mail: kiwig@ur.edu.pl

${ }^{3}$ Ewa Czyż, Wodociągi „Niepołomice” Sp. z o.o., ul. Droga Królewska 27, 32-005 Niepołomice, e-mail: ewa.piorek@o2.pl
} 


\section{Wstęp}

Zbrojenie gruntu polega na umieszczenie w nim elementów wykonanych z innego materiału o odpowiedniej wytrzymałości, przyczepności oraz trwałości. Połączenie gruntu i zbrojenia zapewniają występujące między nimi odpowiednio duże wartości sił tarcia. Zastosowanie zbrojenia pozwala na wytworzenie kompozytu, który w przeciwieństwie do samego gruntu, cechuje się wytrzymałością na rozciąganie $[1,2,3]$.

Pierwsze konstrukcje z gruntu zbrojonego zostały wykonane w czasach starożytnych, gdzie jako zbrojenia używano drewnianych bali i gałęzi, a materiał wypełniający stanowiła glina. Współcześnie zbrojenie gruntów zapoczątkował w latach 60-tych ubiegłego wieku we Francji Henri Vidal, który opatentował wzmacnianie gruntu poziomymi metalowymi taśmami [4]. Obecnie do zbrojenia gruntów wykorzystuje się głównie geosyntetyki (geowłókniny, geotkaniny, geosiatki itp.), a także zbrojenie prętowe i szkieletowe. Materiał wypełniający konstrukcje z gruntu zbrojonego najczęściej stanowią grunty niespoiste, charakteryzujące się dużymi wartościami kąta tarcia wewnętrznego gwarantujące odpowiednią współpracę ze zbrojeniem. Jako wypełnienie konstrukcji z gruntu zbrojonego mogą być również użyte odpady przemysłowe w tym energetyczne, które powstają w wyniku spalania węgla kamiennego lub brunatnego. Do odpadów tych zalicza się m.in.: popioły lotne, żużle oraz mieszaniny popiołowo-żużlowe.

Odpady poenergetyczne wykorzystywane są jako substytut gruntów naturalnych do modernizacji i budowy dróg oraz nasypów hydrotechnicznych, także do rekultywacji i rekonstrukcji terenów zdegradowanych oraz produkcji materiałów budowlanych $[5,6,7]$ co pozwala na zmniejszenie negatywnego ich oddziaływania na środowisko.

Podstawowym kryterium oceny przydatności odpadów poenergetycznych do celów budownictwa drogowego są ich właściwości geotechniczne, których odpowiednie wartości wykluczają powstawanie przełomów i wysadzin na drogach. Odpady poenergetyczne charakteryzują się dużą podatnością na deformacje plastyczne oraz dużą wrażliwością na zmiany wilgotności [8]. Dlatego prawidłowe rozpoznanie ich właściwości geotechnicznych jest istotne dla właściwego ich wykorzystania. Norma [9] dopuszcza stosowanie mieszanin popiołowo-żużlowych zarówno na dolne warstwy nasypów ziemnych poniżej strefy przemarzania jak i na górne warstwy nasypów ziemnych w strefie przemarzania pod warunkiem zalegania ich w miejscach suchych lub izolowanych od wody oraz ulepszenia ich spoiwami hydraulicznymi.

Materiały geosyntetyczne są stosowane w konstrukcjach inżynierskich od kilkudziesięciu lat. W ostatnich latach budownictwo komunikacyjne jest jednym z największych odbiorców tworzyw geosyntetycznych, które służą zarówno do budowy jak i modernizacji dróg lokalnych, krajowych czy autostrad [10]. Wzmocnienie konstrukcji inżynierskiej materiałem geosyntetycznym przyczynia 
się do polepszenia właściwości mechanicznych gruntu, zwiększając jego wytrzymałość na ścinanie [11].

Technologia zbrojenia gruntów geosyntetykami daje możliwość szerokiego jej zastosowania w budownictwie ziemnym. Konstrukcje zbrojone geosyntetykami odpowiednio wpasowują się w krajobraz oraz spełniają wymogi estetyczne. Do korzyści wynikających z ich zastosowania należy również dodać szybkość wykonywania konstrukcji oraz niższe koszty ich realizacji. Zastosowanie geosyntetyków jako zbrojenie gruntów słabych, czy też wzmocnienie konstrukcji ziemnych jest skuteczne i stanowi alternatywę dla tradycyjnych sposobów wzmacniania nasypów i skarp konstrukcji ziemnych [10].

Zastosowanie materiałów geosyntetycznych w konstrukcjach inżynierskich wymaga badań określających parametry współpracy układu: materiał gruntowy geosyntetyk. Niewłaściwie dobrany geosyntetyk może przyczynić się do obniżenia wytrzymałości gruntu, a tym samym spowodować awarię konstrukcji. Określenie parametrów współpracy pomiędzy gruntem, a geosyntetykiem przeprowadza się w aparacie bezpośredniego ścinania, gdzie następuje przesuw próbki gruntu po geosyntetyku lub przez wyciąganie geosyntetyku umieszczonego pomiędzy dwoma warstwami gruntu (,,pull-out test") [11, 12]. Parametrami opisującymi opór tarcia międzyfazowego są kąt tarcia międzyfazowego i adhezja. Badania tych parametrów powinny być przeprowadzane dla każdego rodzaju materiału zasypki i geosyntetyku zastosowanego w konstrukcji z gruntu zbrojonego.

\section{Cel i zakres badań}

Celem badań była określenie wytrzymałości na ścinanie mieszaniny popiołowo-żużlowej ze składowiska odpadów Elektrociepłowni Kraków (EDF Polska S.A.) oraz parametrów oporów tarcia międzyfazowego na kontakcie pomiędzy przedmiotową mieszaniną a geowłókniną PPST 100.

Podstawowe właściwości fizyczne oraz parametry zagęszczalności oznaczono metodami standardowymi. Skład uziarnienia określono metodą łączoną, to jest sitową dla ziarn większych od $0,063 \mathrm{~mm}$ oraz areometryczną dla cząstek mniejszych, a gęstość właściwą szkieletu metodą kolby miarowej w wodzie destylowanej.

Kapilarność bierną oznaczono w kapilarymetrze laboratoryjnym, a wskaźnik piaskowy w cylindrze z pleksiglasu o średnicy wewnętrznej $32 \mathrm{~mm}$ i wysokości $0,43 \mathrm{~m}$. Badania miały na celu ocenę wysadzinowości mieszaniny popiołowo-żużlowej. Parametry zagęszczalności oznaczono w aparacie Proctora, w cylindrze o objętości $2,2 \mathrm{dm}^{3}$ przy energii zagęszczania $0,59 \mathrm{~J} \cdot \mathrm{cm}^{-3}$.

Badania wytrzymałości na ścinanie i oporu tarcia międzyfazowego przeprowadzono $\mathrm{w}$ aparacie bezpośredniego ścinania w skrzynce o przekroju poprzecznym $0,1 \times 0,1 \mathrm{~m}$ i wysokości próbki $38 \mathrm{~mm}$ (wytrzymałość na ścinanie) i $31 \mathrm{~mm}$ (opór tarcia międzyfazowego) z 5 ramkami pośrednimi tworzącymi strefę ścięcia o grubości $10 \mathrm{~mm}$ zgodnie z [13]. Schemat skrzynki aparatu bez- 
pośredniego ścinania w przeprowadzonych badaniach przedstawiono na rysunku 1. Próbki do badań formowano bezpośrednio w skrzynce aparatu przez jej zagęszczanie przy wilgotności optymalnej do uzyskania wskaźnika zagęszczenia $\mathrm{I}_{\mathrm{s}}=0,90$ i 1,00. Próbki po uformowaniu poddano 15 minutowej konsolidacji przy obciążeniu pionowym o wielkości 50, 100, 150, 200, 300 lub $400 \mathrm{kPa}$, a następnie ścinano z prędkością $0,2 \mathrm{~mm} \cdot \mathrm{min}^{-1}$, do uzyskania $10 \%$ odkształcenia poziomego próbki. Jako kryterium ścięcia przyjęto maksymalną wartość naprężeń ścinających.

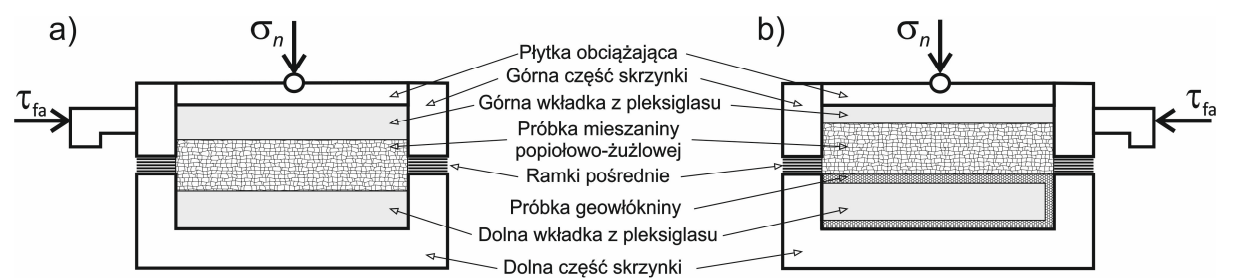

Rys. 1. Schemat skrzynki aparatu bezpośredniego ścinania do badań wytrzymałości na ścinanie (a) i oporu tarcia międzyfazowego (b)

Fig. 1. Scheme of the direct shear apparatus box for shear strength (a) and interphase friction resistance (b) tests

W przypadku badań oporu tarcia międzyfazowego w dolnej część skrzynki znajdowała się wkładka z płytki pleksiglasu, na której mocowano próbkę geowłókniny na wysokości odpowiadającej dolnej powierzchni strefy ścięcia. Próbka mieszaniny była formowana bezpośrednio na geowłókninie.

Badania wytrzymałości na ścinanie i oporu tarcia międzyfazowego wykonano również na próbkach przygotowanych jak wyżej podano lecz wstępnie nawodnionych przez zanurzenie skrzynki w wodzie przez 1 godzinę, a następnie ścinanych przy zawodnieniu strefy ścinania.

\section{Charakterystyka badanych materiałów}

Zgodnie z nomenklaturą geotechniczną [14] mieszaninę popiołowożużlową sklasyfikowano jako kilkufrakcyjny piasek drobny pylasty (siFSa). W składzie uziarnienia dominowała frakcja piaskowa, której było blisko 59\%. Zawartość frakcji pyłowej wynosiła ponad 32\%, żwirowej było ponad $7 \%$, a iłowej około $2 \%$ (tab. 1).

Gęstość właściwa szkieletu wynosiła $2,42 \mathrm{t} \cdot \mathrm{m}^{-3}$, natomiast maksymalna gęstość objętościowa szkieletu $1,13 \mathrm{t} \cdot \mathrm{m}^{-3}$ przy wilgotności optymalnej $38,5 \%$. Kapilarność bierna wynosiła $0,84 \mathrm{~m}$, natomiast wskaźnik piaskowy $18,9 \%$.

Mieszanina popiołowo-żużlowa ze względu na dużą zawartość cząstek mniejszych od 0,075 i 0,02 mm oraz mały wskaźnik piaskowy zakwalifikowano do gruntów wysadzinowych [9]. 
Tabela 1. Właściwości geotechniczne mieszaniny popiołowo-żużlowej

Table 1. Geotechnical properties of the ash-slag mixture

\begin{tabular}{|l|c|}
\hline \multicolumn{1}{|c|}{ Parametr } & Wartość \\
\hline Zawartość frakcji [\%]: & 7,5 \\
- żwirowa: $63 \div 2 \mathrm{~mm}$ & 58,6 \\
- piaskowa: $0 \div 0,063 \mathrm{~mm}$ & 32,3 \\
- pyłowa: $0,063 \div 0,002 \mathrm{~mm}$ & 1,6 \\
- iłowa: $<0,002 \mathrm{~mm}$ & Piasek drobny pylasty (siFSa) \\
\hline Nazwa wg [14] & 58,5 \\
\hline \multirow{2}{*}{ Zawartość cząstek [\%]: } & 27,5 \\
\hline Wskaźnik jednorodności uziarnienia [-] & 10,6 \\
\hline Wskaźnik krzywizny uziarnienia [-] & 1,34 \\
\hline Wilgotność optymalna [\%] & 38,45 \\
\hline Maksymalna gęstość objętościowa szkieletu [t· $\left.{ }^{-3}\right]$ & 1,13 \\
\hline Gęstość właściwa szkieletu [t· $\left.\mathrm{m}^{-3}\right]$ & 2,42 \\
\hline Kapilarność bierna [m] & 0,84 \\
\hline Wskaźnik piaskowy [\%] & 18,9 \\
\hline
\end{tabular}

W badaniach oporu tarcia międzyfazowego na kontakcie mieszanina popiołowo-żużlowa a geosyntetyk, wykorzystano geowłókninę PPST 100. Geowłókniny z serii GEODREN PPST produkowane są z wysokiej jakości białych włókien polipropylenowych, połączonych metodą mechaniczną, bez dodatków kleju i substancji chemicznych. Geosyntetyki te znalazły zastosowanie w budownictwie wodnym, drogowym i kolejowym oraz tuneli. Wykorzystywane są w konstrukcjach nawierzchni nasypów budowlanych na słabych gruntach oraz jako materiał filtracyjny w ochronie przed erozją brzegów rzek, kanałów, wybrzeży morskich $[15,16]$. Podstawowe właściwości fizyczne geowłókniny PPST 100 przedstawiono w tabeli 2.

Tabela 2. Właściwości fizyczne geowłókniny PPST 100, na podstawie [16]

Table 2. Physical properties of the nonwoven geotextile PPST 100, based on [16]

\begin{tabular}{|l|c|}
\hline \multicolumn{1}{|c|}{ Parametr } & Wartość \\
\hline Masa jednostkowa $\left[\mathrm{g} \cdot \mathrm{m}^{-2}\right]$ & 100 \\
\hline Grubość $[\mathrm{mm}]$ & 0,55 \\
\hline Wytrzymałość na rozciąganie $\left[\mathrm{kN} \cdot \mathrm{m}^{-1}\right]$ & 7 \\
\hline Wydłużenie przy zerwaniu $[\%]$ & 55 \\
\hline Odporność na przebicie statyczne $\left[\mathrm{kN} \cdot \mathrm{m}^{-1}\right]$ & 1,2 \\
\hline Odporność na przebicie dynamiczne $[\mathrm{mm}]$ & 38 \\
\hline Prędkość przepływu wody $\left[\mathrm{mm} \cdot \mathrm{s}^{-1}\right]$ & 125 \\
\hline Charakterystyczny rozmiar porów $[\mu \mathrm{m}]$ & 120 \\
\hline
\end{tabular}




\section{Wyniki badań}

\section{Wytrzymatość na ścinanie}

Stwierdzono, że wzrost zagęszczenia od $\mathrm{I}_{\mathrm{S}}=0,90$ do 1,00 oraz naprężeń normalnych spowodował zwiększenie wytrzymałości na ścinanie mieszaniny popiołowo-żużlowej (rys. 2).

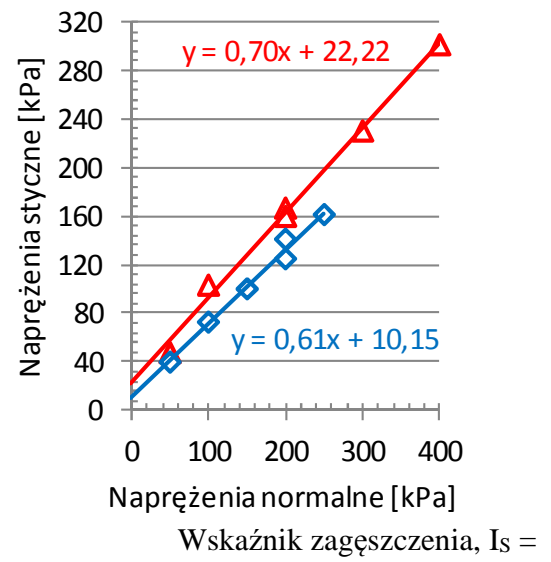

b)

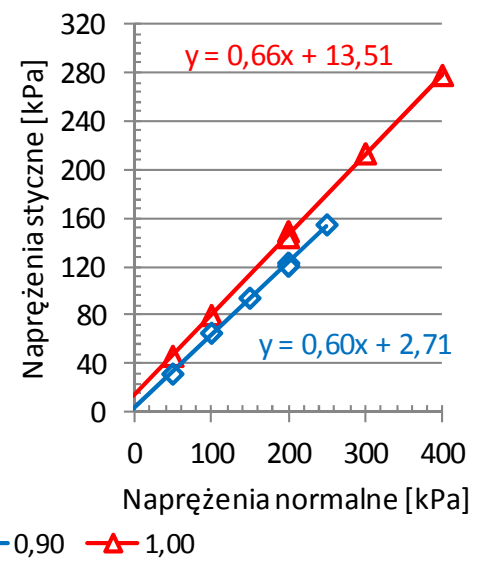

Rys. 2. Zależność naprężeń stycznych od normalnych w badaniach wytrzymałości na ścinanie przy różnym zagęszczeniu próbek nienawodnionych (a) i nawodnionych (b)

Fig. 2. Tangential stress versus normal stress in shear strength tests at different compaction of the unsaturated (a) and saturated (b) samples

Wytrzymałość na ścinanie mieszaniny popiołowo-żużlowej zależała od zagęszczenia i warunków wodnych. Zwiększenie wskaźnika zagęszczenia od $\mathrm{I}_{\mathrm{S}}=0,90$ do 1,00 spowodował zwiększenie wytrzymałości na ścinanie zależne od wartości naprężeń normalnych i tak:

- w przypadku próbek nienawodnionych przy naprężeniach normalnych równych $50 \mathrm{kPa}$ wytrzymałość na ścinanie zwiększyła się o $8 \mathrm{kPa}(19 \%$ względnych), a przy naprężeniach $200 \mathrm{kPa}$ o $30 \mathrm{kPa}$ (o 23\%),

- w przypadku próbek nawodnionych przy naprężeniach normalnych równych 50 i $200 \mathrm{kPa}$ stwierdzono zwiększenie wytrzymałości na ścinanie odpowiednio o $15 \mathrm{kPa}$ (46\% względnych) i $25 \mathrm{kPa}$ (o $20 \%)$.

Stwierdzono również istotny wpływ nawodnienia na wytrzymałość na ścinanie. Większe jej wartości uzyskano z badań próbek nienawodnionych. Przy naprężeniach normalnych $50 \mathrm{kPa}$ było to zwiększenie od 8 do nieco ponad $1 \mathrm{kPa}$ (o 26 i 3\%), a przy naprężeniach $200 \mathrm{kPa}$ od 11 do blisko $17 \mathrm{kPa}$ (o 9 i 12\%) odpowiednio przy zagęszczeniu $I_{S}=0,90$ i 1,00. Można więc stwierdzić, że zabezpieczenie badanego materiału przed kontaktem z wodą pozwoli osiągnąć wyższe wartości parametrów wytrzymałości na ścinanie. 
Wzrost zagęszczenia od IS $=0,90$ do 1,00 spowodował zwiększenie wartości kąta tarcia wewnętrznego i spójności mieszaniny popiołowo-żużlowej (tab. 3) i tak:

- w przypadku próbek nienawodnionych zwiększenie kąta tarcia wewnętrznego wynosiło blisko $4^{\circ}$ (11\%) (rys. 3a), a spójności $12 \mathrm{kPa}$ (ponad 2-krotnie) (rys. 3b),

- w przypadku próbek nawodnionych kąt tarcia wewnętrznego zwiększył się o nieco ponad $2^{\circ}(8 \%)$, a spójność o $11 \mathrm{kPa}$ (4-krotnie).

Tabela 3. Wartości parametrów wytrzymałości na ścinanie mieszaniny popiołowo-żużlowej i oporu tarcia międzyfazowego na kontakcie mieszanina a geowłóknina

Table 3. Values of the shear strength parameters of the ash-slag mixture and interfacial friction resistance at the contact of mixture and nonwoven geotextile

\begin{tabular}{|c|c|c|c|c|}
\hline \multirow{4}{*}{ Parametr } & \multicolumn{4}{|c|}{ Próbki } \\
\hline & \multicolumn{2}{|c|}{ bez nawodnienia } & \multicolumn{2}{|c|}{ z nawodnieniem } \\
\hline & \multicolumn{4}{|c|}{ Wskaźnik zagęszczenia [-] } \\
\hline & 0,90 & 1,00 & 0,90 & 1,00 \\
\hline Kąt tarcia wewnętrznego $\left[^{\circ}\right]$ & 31,4 & 35,0 & 31,1 & 33,5 \\
\hline Spójność [kPa] & 10,2 & 22,2 & 2,7 & 13,5 \\
\hline Kąt tarcia międzyfazowego $\left[{ }^{\circ}\right]$ & 27,5 & 28,1 & 28,1 & 30,4 \\
\hline Adhezja [kPa] & 12,1 & 14,8 & 6,5 & 9,6 \\
\hline
\end{tabular}

a)

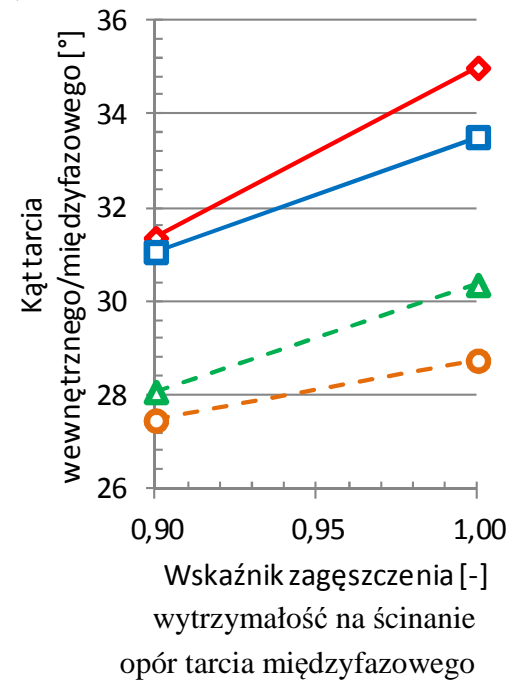

b)

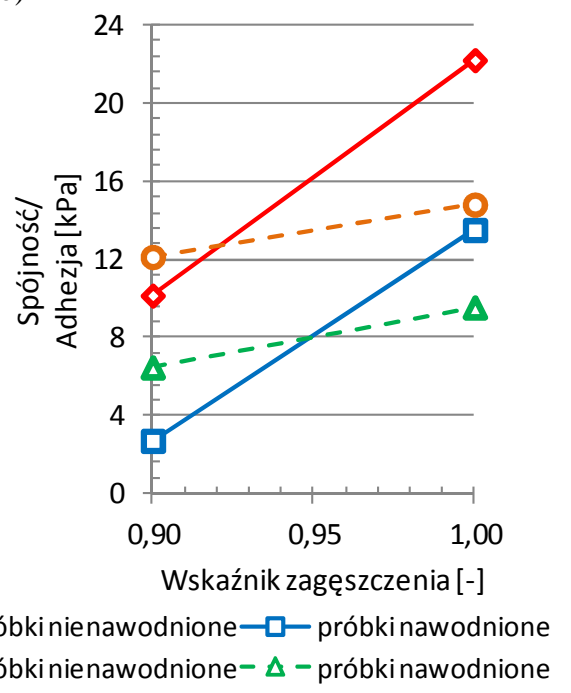

Rys. 3. Wpływ zagęszczenia na parametry wytrzymałości na ścinanie mieszaniny popiołowożużlowej i oporu tarcia międzyfazowego na kontakcie mieszanina a geowłóknina

Fig. 3. Influence of the compaction on the shear strength parameters of the ash-slag mixture and the interfacial friction resistance at the contact of the mixture with the nonwoven geotextile 
Nawodnienie próbek spowodowało zmniejszenie wartości parametrów wytrzymałości na ścinanie, które w przypadku kąta tarcia wewnętrznego wynosiło 0,3 i $1,5^{\circ}$ (1 i 4,5\%), a spójności 7,5 i $8,5 \mathrm{kPa}$ (2,7 i 0,6-krotnie) odpowiednio przy zagęszczeniu $\mathrm{I}_{\mathrm{S}}=0,90$ i 1,00 .

\section{Opór tarcia międzyfazowego}

Opór tarcia międzyfazowego na kontakcie mieszanina popiołowo-żużlowej, a geowłóknina PPST 100 zależał również od zagęszczenia oraz warunków wodnych i tak:

- w badaniach próbek nienawodnionych (rys. 4a) przy naprężeniach normalnych równych $50 \mathrm{kPa}$ opór tarcia międzyfazowego był podobny przy obydwu zagęszczeniach i wynosił około $37 \mathrm{kPa}$, a naprężeniach normalnych wynoszących $200 \mathrm{kPa}$ wzrost zagęszczenia spowodował zwiększenie oporu o blisko $12 \mathrm{kPa}($ o $10 \%)$,

- w badaniach próbek nawodnionych, przy naprężeniach normalnych równych $50 \mathrm{kPa}$ wzrost zagęszczenia spowodował zwiększenie oporu tarcia międzyfazowego o $7 \mathrm{kPa}(21 \%)$, a przy naprężeniach normalnych $200 \mathrm{kPa}$ o blisko $18 \mathrm{kPa}($ o $16 \%)$.

a)

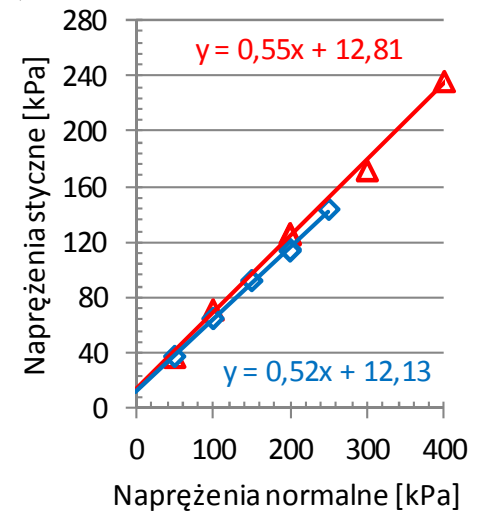

b)

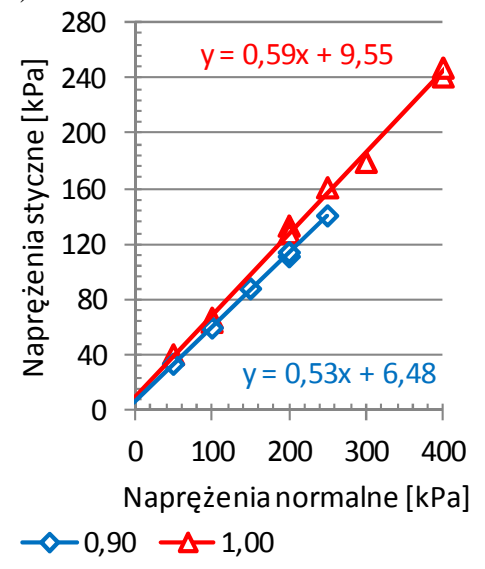

Rys. 4. Zależność naprężeń stycznych od normalnych w badaniach oporu tarcia międzyfazowego przy różnym zagęszczeniu próbek nienawodnionych (a) i nawodnionych (b)

Fig. 4. Tangential stress versus normal stress at the interfacial friction resistance tests, at different compaction of the unsaturated (a) and saturated (b) samples

Porównując wartości oporu tarcia międzyfazowego dla próbek nienawodnionych i nawodnionych stwierdzono, że:

- przy zagęszczeniu $\mathrm{I}_{\mathrm{S}}=0,90$ mniejsze jego wartości o około 2 i $5,5 \mathrm{kPa}$ (o 2 i 9\%) uzyskano dla próbek nienawodnionych, 
- przy zagęszczeniu $\mathrm{I}_{\mathrm{S}}=1,00$ większe wartości oporu tarcia o nieco ponad 3 i blisko $5 \mathrm{kPa}$ (o 9 i $2 \%$ ) uzyskano dla próbek nawodnionych.

Kąt tarcia międzyfazowego wraz ze wzrostem zagęszczenia od $\mathrm{I}_{\mathrm{S}}=0,90$ do 1,00 zwiększył się o blisko $1^{\circ}$ (nieco ponad $2 \%$ ) w badaniach próbek nienawodnionych oraz o nieco ponad $2^{\circ}$ (ponad $8 \%$ ) w badaniach próbek nawodnionych (tab. 3, rys. 3a). Natomiast adhezja zwiększyła się wraz ze wzrostem zagęszczenia o blisko $3 \mathrm{kPa}$ co stanowi ponad 22 i $48 \%$ względne odpowiednio w badaniach próbek nienawodnionych i nawodnionych (rys. 3b).

Kąt tarcia międzyfazowego z badań próbek nienawodnionych był mniejszy o blisko 1 i ponad $2^{\circ}$ (o 2 i $8 \%$ względnych) odpowiednio przy zagęszczeniu $\mathrm{I}_{\mathrm{S}}=0,90$ i 1,00 od wartości z badań próbek nawodnionych. Natomiast adhezja była większa z badań próbek nienawodnionych o nieco ponad $5 \mathrm{kPa}$, a więc o 54 i 86\% względne odpowiednio przy zagęszczeniu $\mathrm{I}_{\mathrm{S}}=0,90$ i 1,00 .

Porównując uzyskane wartości kąta tarcia wewnętrznego i międzyfazowego oraz spójności i adhezji stwierdzono podobną zależność badanych parametrów od zagęszczenia zarówno w badaniach próbek nienawodnionych jak i nawodnionych. Wartości kąta tarcia wewnętrznego były większe o 4 i $7^{\circ}$ od kąta tarcia międzyfazowego odpowiednio przy zagęszczeniu $\mathrm{I}_{\mathrm{S}}=0,90$ i 1,00 (rys. 3a). Natomiast spójność była mniejsza o $2 \mathrm{kPa}$ i większa o ponad $7 \mathrm{kPa}$ od adhezji odpowiednio przy zagęszczeniu $\mathrm{I}_{\mathrm{S}}=0,90$ i 1,00 (rys. 3b).

\section{Analiza porównawcza}

Badania parametrów wytrzymałości na ścinanie mieszanin popiołowożużlowych ze składowiska „Czajki” Elektrociepłowni Zakładów Azotowych w Tarnowie [17] oraz ze składowiska Elektrowni „Skawina” [18] wykazują podobną zależność od zagęszczenia. Analiza wyników badań pozwoliła stwierdzić, że w przypadku badań próbek nienawodnionych największe wartości kąta tarcia wewnętrznego uzyskano dla mieszaniny z Elektrowni „Skawina”, a spójności dla mieszaniny z Elektrociepłowni „Tarnów”. Natomiast prawie takie same wartości kąta tarcia wewnętrznego uzyskano dla mieszaniny z Elektrociepłowni „Kraków” i „Tarnów” oraz podobne wartości spójności dla mieszaniny z Elektrowni „Kraków” i „Skawina”. W przypadku próbek nawodnionych największe wartości kąta tarcia wewnętrznego i spójności uzyskano dla mieszaniny z Elektrociepłowni „Kraków”. Były to wartości większe średnio o $13^{\circ} \mathrm{w}$ przypadku kąta tarcia wewnętrznego przy obydwu zagęszczeniach $\left(\mathrm{I}_{\mathrm{S}}=0,90\right.$ i 1,00$)$, a spójności podobne przy $\mathrm{I}_{\mathrm{S}}=0,90 \mathrm{i}$ większe o $8 \mathrm{kPa}$ przy $\mathrm{I}_{\mathrm{S}}=1,00 \mathrm{od}$ wartości dla mieszaniny z Elektrowni „Skawina”.

Należy zaznaczyć, że przyrost parametrów wytrzymałości na ścinanie wraz ze wzrostem zagęszczenia dla analizowanych mieszanin popiołowo-żużlowych był podobny.

Badania oporu tarcia międzyfazowego Gruchota [19] oraz Gruchota i Zydronia [12] na kontakcie mieszanina popiołowo-żużlowa z Elektrowni „Skawi- 
na" a geowłóknina Secutex 401-GRK 5C oraz geotkanina ACETex GT 40/40 wykazały, że wzrost zagęszczenia od Is $=0,90$ do 1,00 spowodowało zwiększenie wartości kąta tarcia międzyfazowego o $5^{\circ}$ (o 15\%). Natomiast w badaniach mieszaniny popiołowo-żużlowej z Elektrociepłowni „Kraków” oraz geowłókniny PPST 100 wzrost zagęszczenia spowodował pomijalnie małe zwiększenie kąta tarcia międzyfazowego. W przypadku adhezji uzyskano zwiększenie jej wartości o około $1 \mathrm{kPa}$ i $4 \mathrm{kPa}$ na kontakcie mieszanina z Elektrowni „Skawina” oraz odpowiednio geotkanina ACETex GT 40/40 i geowłóknina Secutex 401GRK 5C.

\section{Podsumowanie}

Parametry wytrzymałości na ścinanie mieszaniny popiołowo-żużlowej z Elektrociepłowni „Kraków” były duże. Stwierdzono istotny wpływ zagęszczenia, którego wzrost spowodował zwiększenie badanych parametrów. Natomiast nawodnienie próbek spowodowało zmniejszenie parametrów wytrzymałości na ścinanie. Dlatego stosując mieszaninę do celów budownictwa ziemnego należy stosować warstwy ochronne przed wodami gruntowymi lub opadowymi.

Parametry charakteryzujące opór tarcia międzyfazowego na kontakcie mieszanina popiołowo-żużlowa - geowłóknina były również duże, co pozwala stwierdzić jej przydatność jako materiał zasypki w konstrukcjach z gruntów zbrojonych. Należy również wskazać, ze nawodnienie próbek spowodowało zwiększenie kąta tarcia międzyfazowego i zmniejszenie adhezji.

Podsumowując można stwierdzić, że stosowanie mieszanin popiołowożużlowych jako kruszyw antropogenicznych jest ważnym i istotnym zagadnieniem $w$ aspekcie ochrony naturalnych materiałów gruntowych.

\section{Literatura}

[1] Ajdukiewicz J.: Projektowanie z geosyntetykami - możliwe zagrożenia dla projektantów - cz. I, Autostrady, 5, 2004, s. 84-90.

[2] Ajdukiewicz J.: Projektowanie z geosyntetykami - możliwe zagrożenia dla projektantów - cz. II. Inne, popełniane w procesie projektowania błędy w odniesieniu do pracujących w reżimie wytrzymałościowym materiałów geosyntetycznych, Autostrady, 6, 2004, s. 20-27.

[3] Sobolewski J.: Wymiarowanie zbrojeń geosyntetycznych w konstrukcjach z gruntu zbrojonego zgodnie z przepisami Eurokodu 7, Instytut Badawczy Dróg i Mostów. Drogi i Mosty, 2, 2010, s. 73-86.

[4] Sawicki A., Leśniewska D.: Grunt zbrojony, teoria i zastosowanie, Państwowe Wydawnictwo Naukowe PWN, Warszawa 1993.

[5] Borys M., Filipowicz P.: Wykorzystanie odpadów przemysłowych do budowy i umacniania wałów przeciwpowodziowych. Instytut Melioracji i Użytków Zielonych w Falentach. Rocznik Ochrona środowiska, 10, 2008, s. 633-644. 
[6] Gruchot A.: Utylizacja odpadów powęglowych i poenergetycznych do celów inżynierskich jako czynnik kształtowania i ochrony środowiska, Zeszyty Naukowe Uniwersytetu Rolniczego w Krakowie, Rozprawy, 2016, ss. 410.

[7] Sybilski D., Kraszewski C.: Ocena i badania wybranych odpadów przemysłowych do wykorzystania w konstrukcjach drogowych, Instytut Badawczy Dróg i Mostów, Warszawa 2004.

[8] Gruchot A., Zydroń T.: Właściwości geotechniczne mieszaniny popiołowo-żużlowej ze spalania węgla kamiennego w aspekcie jej przydatności do celów budownictwa ziemnego. Środkowo-Pomorskie Towarzystwo Naukowe Ochrony Środowiska. Rocznik Ochrona Środowiska, 15(2), 2013, s. 1719-1737.

[9] PN-S-02205:1998. Drogi samochodowe. Roboty ziemne. Wymagania i badania. Polski Komitet Normalizacyjny, Warszawa.

[10] Janusz L., Zawisza M.: Funkcje spełniane przez materiały geosyntetyczne w konstrukcjach inżynierskich, XXVII Zimowa Szkoła Mechaniki Górotworu, 2004, s. 371-380.

[11] Duszyńska A., Bolt A.: Współpraca georusztu i gruntu w badaniu na wyciąganie. Wydawnictwo Politechniki Gdańskiej, Gdańsk 2004.

[12] Gruchot A., Zydroń T.: Określenie oporów tarcia na kontakcie wybranych odpadów paleniskowych z geosyntetykami. Acta Scientiarum Polonorum, Architectura, 14(4), 2015, s. 35-47.

[13] PKN-CEN ISO/TS 17892-10:2009. Badania geotechniczne. Badania laboratoryjne gruntów. Część 10: Badanie w aparacie bezpośredniego ścinania. Polski Komitet Normalizacyjny, Warszawa.

[14] PN-EN ISO 14688-1:2006. Badania geotechniczne. Oznaczanie i klasyfikowanie gruntów. Część 1: Oznaczanie i opis. Polski Komitet Normalizacyjny, Warszawa.

[15] www.drotest.com.pl - serwis internetowy firmy Biuro Inżynierii Drogowej Drotest Józef Judycki, Jacek Alenowicz Sp. j. (dostęp 06.04.2016).

[16] www.gunnex.pl - serwis internetowy firmy GUNNEX PL Sp. z o.o. (dostęp 26.04.2016).

[17] Gruchot A., Ligas E.: Wytrzymałość na ścinanie mieszanek popioło-żużli z piaskiem. Przegląd Górniczy, 12, 2012, s. 123-127.

[18] Gruchot A., Resiuła E.: Wpływ zagęszczenia i nawodnienia na wytrzymałość na ścinanie mieszaniny popiołowo-żużlowej i stateczność wykonanego z niej nasypu. Górnictwo i Geoinżynieria, 2, 2011, s. 257-264.

[19] Gruchot A.: Opory tarcia na kontakcie mieszanina popiołowo-żużlowa a geowłóknina. Acta Scientiarum Polonorum, Formatio Circumiectus, 12(4), 2013, s. 55-65.

\section{INTERPHASE CONTACT PARAMETERS OF THE CHOSEN MATERIALS USED IN EARTH STRUCTURES}

\section{S u m m a r y}

The tests aimed at the determination of the shear strength of the ash-slag mixture from the landfill of the Combined Heat and Power Plant „Kraków” S.A. (EDF Polska S.A.) as well as the interphase friction resistance at the contact between the mixture in question and the PPST 100 
geotextile. The tests were conducted in a direct shear apparatus. Samples for the tests were formed in the apparatus box at the optimum moisture content by compacting them to Is $=0.90$ and 1.00 . Shearing of the samples was carried out without and with their saturation.

The shear strength parameters of the ash-slag mixture were large. It was stated the significant influence of the compaction, the growth of which has resulted in an increase in the angle of internal friction and cohesion. Whereas the saturation of the samples reduced the shear strength parameters. The values of the interphase friction resistance at the contact: the ash-slag mixture and the geotextile were large as well. It should also be noted that the saturation of the samples increased the angle of interphase friction and decreased the adhesion. It can be concluded that the use of the ash-slag mixtures as anthropogenic aggregates is an important issue in terms of protection of natural soil materials.

Keywords: ash-slag mixture, shear strength, interphase friction resistance, nonwoven geotextiles

Przestano do redakcji: $6.06 .2017 \mathrm{r}$.

Przyjęto do druku: 01.09.2017 r. 